\title{
Macroanatomical Investigations on Renal Arteries of Southern Karaman Sheep
}

\author{
Derviş Özdemir ${ }^{1, a, *}$, Zekeriya Özüdoğrư ${ }^{2, b}$ \\ ${ }^{1}$ Department of Anatomy, Faculty of Veterinary Medicine, Atatürk University, 25240 Erzurum, Turkey \\ ${ }^{2}$ Department of Anatomy, Faculty of Veterinary Medicine Aksaray University, 68100 Aksaray, Turkey \\ *Corresponding author

A R T I C L E I N F O A B S T R A C T

\begin{tabular}{l|l}
\hline Research Article & $\begin{array}{l}\text { In this study, it was aimed to investigate the arterial vascularization of the kidneys in the South } \\
\text { Karaman sheep breed. Twelve South Karaman sheep kidneys were used in the study. The course of } \\
\text { the renal arteries in the kidney was examined by means of dissection and corrosion cast techniques. } \\
\text { The kidneys were vascularized with right renal artery and left renal artery to the arteries originating } \\
\text { from the abdominal aorta. Right renal artery was seen to be slightly more prominent than the left } \\
\text { renal artery. Left renal artery was measured longer and thicker than the right renal artery. The renal } \\
\text { artery entering the renal hilus, dorsal and ventral part of the renal artery were detected. However, } \\
\text { in several materials, the left renal artery was shown to have a third branch. The dorsal and ventral } \\
\text { branches gave interlobar artery with numbers ranging from 2-5. Each interlobar artery had multiple } \\
\text { arcuate artery. These arteries ended by giving the interlobular artery. Anastomosis was not observed } \\
\text { between the renal arteries. Although there were some important variations in the distribution of } \\
\text { renal arteries of South Karaman sheep, similar findings were reported in the literature. }\end{array}$ \\
$\begin{array}{l}\text { Keywords: } \\
\text { Intrarenal segmentation } \\
\text { Southern Karaman sheep }\end{array}$ &
\end{tabular} \\ Southern Karaman sheep
}

Ren

Anatomy

Renal artery

\section{Introduction}

Sheep breeding livestock and rural economy in terms of Turkey is very important. A significant portion of the total red meat and milk production in Turkey is from sheep.

South Karaman sheep is cultivated in South Taurus region. Southern Karaman sheep are black, brown, and gray, white or black (Tufan and Akmaz, 2001).

The excretory system consists of a pair of kidneys, ureters carrying urine, urethra that urinates and urethra which exudes urine (Dyce et al., 2002). The main functional part of the urinary system is the kidneys. Kidneys remove the residues and excess water formed as a result of metabolic activity from the body (Dursun, 2008; Konig and Liebich, 2007).

To know the distribution of renal arteries, urological and surgical techniques in the implementation, kidney transplant operations provide convenience. The aim of this study was to investigate the anatomical distribution of renal arteries in Karaman sheep.

\section{Materials and Methods}

Twelve South Karaman sheep kidneys were used as research material. The kidneys were taken together with their arteries, then $20 \%$ powdered monomethylmethacrylate and $80 \%$ liquid polymethyl-methacrylate was prepared by injection of the prepared takilon. The casting corrosion method (Nerantsiz et al., 1978; Tompset, 1970) was applied these materials. For polymerization, the materials were kept at room temperature for 24 hours. They were exposed to corrosion in $30 \% \mathrm{KOH}$ at $60^{\circ} \mathrm{C}$ for 24 hours. After dissolving soft tissues, the remainder was removed from the corrosion casts in running water. The corrosion casts were dried at room temperature. Data on prepared casts were recorded using digital caliper and digital camera (Olympus Camedia 4000 Japan). This study was conducted in accordance with ethical principles of animal experiments. 


\section{Results}

In South Karaman sheep, each kidney was found to originate from the ventral wall of the abdominal aorta. The origin of the right renal artery was found to be cranial on the origin of the left renal artery. Left renal artery was found to be longer and thicker than the right renal artery. The average diameter of abdominal aorta was $10.15 \mathrm{~mm}$. The average length between the right and left arteries was $11.32 \mathrm{~mm}$ (Figure 1-2).

The length of the right renal artery was $24.5-49.7 \mathrm{~mm}$, and the length of the left renal artery was $36.8-65.3 \mathrm{~mm}$. The mean right renal artery diameter was $3.56 \mathrm{~mm}$ and the mean left renal artery diameter was $4.04 \mathrm{~mm}$. Each renal artery was divided into dorsal and ventral branches (Figure 3-4).

The diameter of the right dorsal branches was about 2.40 to $3.34 \mathrm{~mm}$ and the length were 6.53 to $13.31 \mathrm{~mm}$. Ramus dorsalis had three or six interlobar artery (Figure 3 ). The diameter of the left dorsal branches was approximately

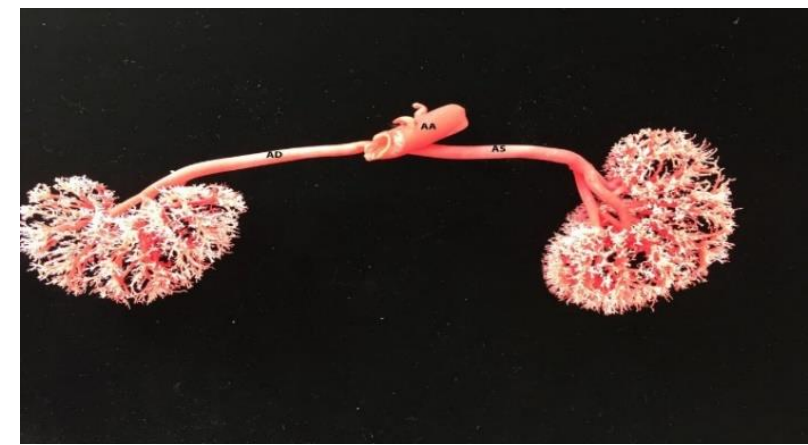

Figure 1. Dorsal view of the renal arteries. AA-aorta abdominalis, AD-arteria renalis dextra, AS-arteria renalis sinistra.

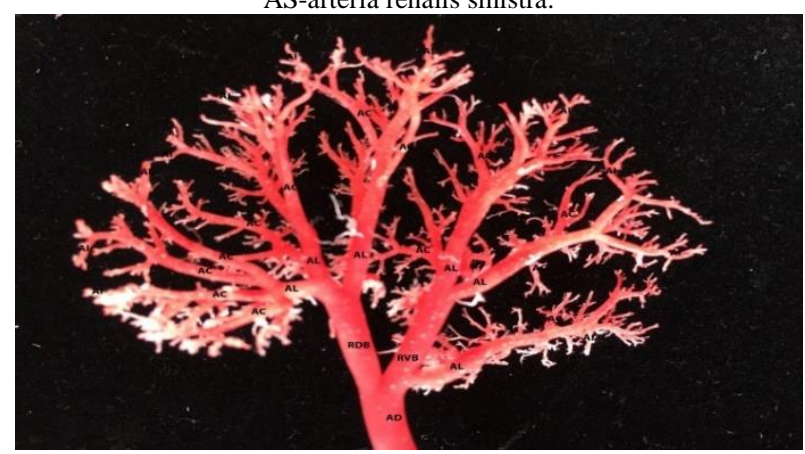

Figure 3. Dorsal view of the right renal artery.

$\mathrm{AD}$ - arteria renalis dextra, RDB-right dorsal branch, RVB-right ventral branch, AL-interlobar artery,

AC-arcuate artery, AI- interlobular artery.

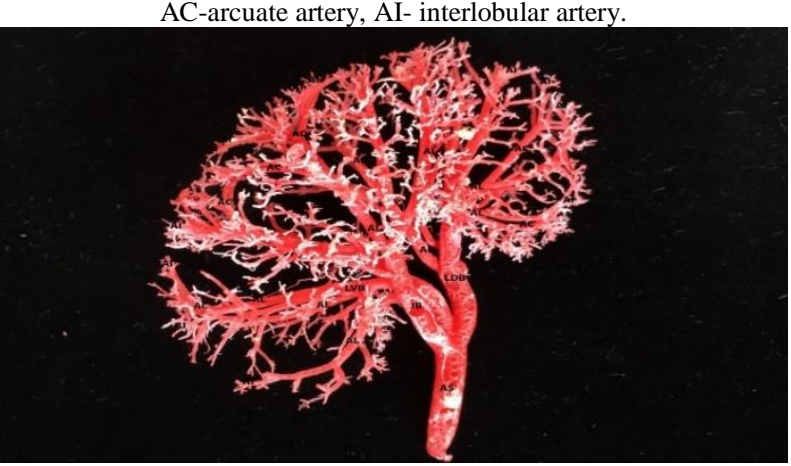

Figure 5. Dorsal view of the left renal artery.

AS- arteria renalis sinistra, LDB-left dorsal branch, LVB-left ventral branch, JB-An artery that feeds both the dorsal and ventral surfaces of the kidney, AL-interlobar artery, AC-arcuate artery, AI- interlobular artery.
2.51 to $3.31 \mathrm{~mm}$ and the length were 10.05 to $17.50 \mathrm{~mm}$. It had four or six interlobar artery (Figure 4). The diameter of the right ventral branch was approximately 2.46 to 3.40 $\mathrm{mm}$ and its length were 7.10 to $13.16 \mathrm{~mm}$. It had four to six interlobar artery (Figure 5). The diameter of the left ventral branch was approximately 2.43 to $3.62 \mathrm{~mm}$ and the length were 8.99 to $16.71 \mathrm{~mm}$. It had three to four interlobar artery (Figure 6). In a few of the left kidneys, there was a third branch in addition to the dorsal and ventral branches. This third branch had 2-3 interlobar artery (Figure 5-6).

Interlobar artery gave the arteria arcuate passing through the base of the medullary pyramids at the medullacortex junction. Arcuate artery from the arteries of the interlobular is, the whole surface of the kidney is feeding. Anastomosis was not observed between the renal arteries.

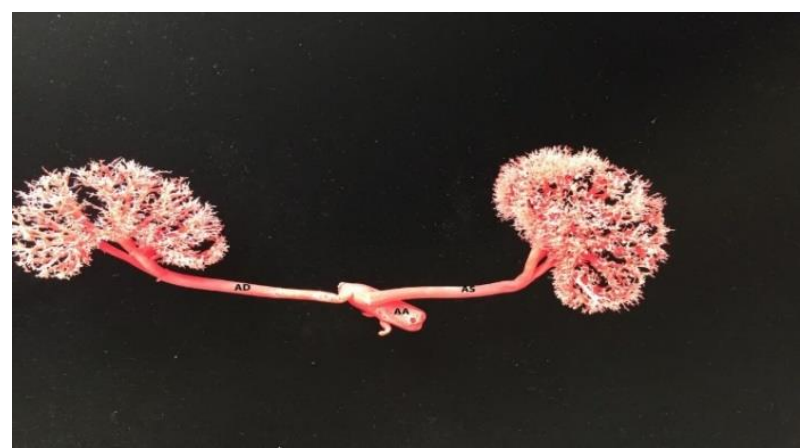

Figure 2. Ventral view of the renal arteries. AA-aorta abdominalis, AD-arteria renalis dextra, AS-arteria renalis sinistra.

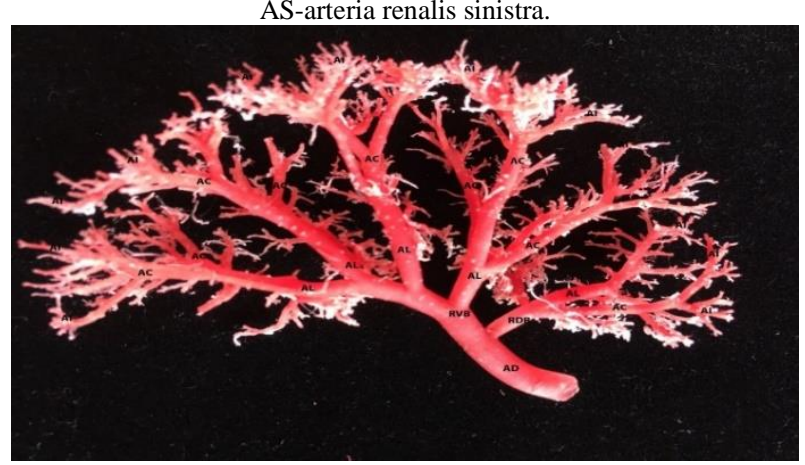

Figure 4. Ventral view of the right renal artery. $\mathrm{AD}$-arteria renalis dextra, RDB-right dorsal branch, RVB-right ventral branch, AL-interlobar artery,

AC-arcuate artery, AI- interlobular artery.

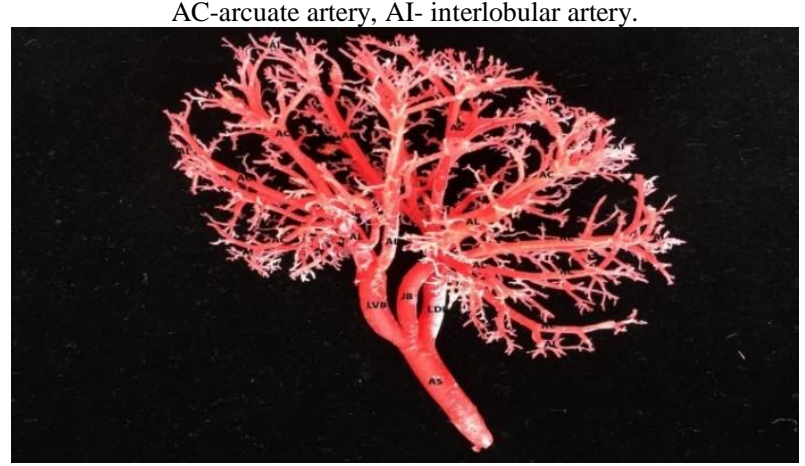

Figure 6. Ventral view of the left renal artery.

AS- arteria renalis sinistra, JB-An artery that feeds both the dorsal and ventral surfaces of the kidney, LDB-left dorsal branch, LVB-left ventral branch, AL-interlobar artery,

$\mathrm{AC}$-arcuate artery, AI- interlobular artery. 


\section{Discussion}

Renal artery originates from different parts of the abdominal aorta. In the literature, it has been reported that the renal artery, the ventral (Shively, 1978; Ghoshal, 1975), lateral (Atalar and Yilmaz, 2004), ventrolateral (Cakir, 1991), or both sides of the abdominal aorta (Yoldas et al, 2014; Aksoy et al., 2004; Nickel et al., 1981; Mohamed, 2014). In this study, it was observed that the renal artery from the ventral side of the abdominal aorta.

In the rabbits (Mazensky et al., 2012; Nowicki et al., 2010), the renal artery is present only as double renal arteries on the left side, whereas in the dogs (Shively, 1978; Christensen, 1952; Wiland and Indykiewicz, 1999; Kurtul et al., 2002) the renal artery are present as double renal arteries in both sides of the aorta. Loukas et al. (2005) indicated that three renal artery on the right side and there was an accessory renal artery which appeared as a common body with an inferior mesenteric artery on the right side. In this study, double renal artery was found in any material.

There are several reports about the length of the right and left arteries. In some sources (Mohamed, 2014; Nickel et al., 1979; Aksoy and Ozudogru, 2003; Ozudogru and Ozdemir, 2005; Ozudogru et al., 2018), the left renal artery was reported to be longer and in some other sources (Aksoy et al., 2004; Nickel et al., 1979; Ozdemir et al., 2009; Paryani, 2012) the right renal artery was longer. In all of the materials examined, it was determined that the left renal artery was longer than the right renal artery.

It was observed that the renal arteries from the renal hilus were divided into dorsal and ventral branches. Subsequently, the dorsal and ventral branches gave more than one interlobar artery. The interlobular arteries gave the arcuata artery at the medulla-cortex junction. Findings related to the branching of kidney arteries are in parallel with the literature (Yoldas et al., 2014; Aksoy et al., 2004; Ozudogru and Ozdemir, 2005; Ozdemir et al., 2009). Mazensky and Flesarova (2017) reported that the renal artery was divided into two, three or four branches.

The right dorsal branch was divided into three interlobar branches and the right ventral branch was divided into four interlobar branches. On the other hand, the left dorsal branch was divided into four to five branches and the left ventral branch to four to five branches. Left renal artery, dorsal and ventral branch as well as a third branch was given. This branch was also dorsal and ventral subbranches. Aksoy et al. (2004) reported that the right dorsal branch was divided into three interlobar artery, the right ventral branch divided into four interlobar artery, the left dorsal branch divided into three interlobar artery and the left ventral branch gave three or four interlobar artery. In the right kidney of the Tuj sheep, it was reported that an interlobar artery originating from the dorsal branch of the dorsal and ventral branches of the kidney, feeding the dorsal surface of the kidney and feeding the last part of the ventral surface in the left kidney.

In many studies on the distribution of renal artery (Aksoy et al., 2004; Aksoy and Ozudogru, 2003; Ozudogru and Ozdemir, 2005; Ozdemir et al., 2009; Evan et al., 1996; Marques-Sampio et al., 2007; Pereira-Sampio et al., 2009), anastomosis was not observed between the arteries. However, it is reported that Morkaraman sheep (Aslan and Nazli, 2001) and anastomosis in rat (Nur and Yoldas, 2011) kidneys. No anastomosis was observed between the renal arteries.
In conclusion, this study, in which the renal arteries were examined, could be used as a reference to the surgeons in anatomical terms in order to prevent damage to these arteries during renal transplantation in urological areas.

\section{References}

Aksoy G, Kurtul I, Ozcan S, Aslan K, Ozudogru Z. 2004. Intrarenal arteries and their patterns in the Tuj sheep. Vet. Med., 49: 57-60.

Aksoy G, Ozudogru Z. 2003. A macroscopical investigation on the intrarenal segmentation of the renal arteries in the Van cat. Journal of Kafkas Faculty Veterinary Medicine, 9: 9-13.

Atalar O, Yilmaz S. 2004. Macroanatomical investigation of the renal arteries in the porcupines (Hystrix cristata). Firat University, Journal of Health Sciences, 18: 51-53.

Aslan K, Nazli MA. 2001. Comparative macro-anatomic investigation on the intrarenal segmentation of the renal artery in goats and morkaraman sheep. Indian Veterinary Journal, 78: 139-143.

Cakir A. 1991. Yerli Kedi (Felis domestica L.) ve Beyaz Yeni Zelanda Tavşan'ının (Orcytolagus cuniculus L.) Aorta Abdominalis'i ve Verdiği Kollar Üzerinde Karşılaştırmalı Anatomik Çalışmalar. Doktora Tezi. Ankara Üniv. Sağlık Bilimleri Enstitüsü, Ankara- Türkiye.

Christensen GC. 1952. Circulation of Blood through the Canine Kidney. Am. J. Vet. Res., 13: 236-245.

Dursun N. 2008. Veteriner Anatomi II. 11. Bask1. Ankara: Medisan Yayınevi, pp.:128-163.

Dyce KM, Sack WO, Wensing CJG. 2002. Textbook of Veterinary Anatomy. 3rd edition, Saunders, Philadelphia, pp.:174-184.

Evan AP, Connors BA, Lingeman JE, Blomgren P, Willis LR. 1996. Branching patterns of the renal artery of the pig. Anat. Rec., 246: 217-23.

Ghoshal NG. 1975. Ruminant heart and arteries. In: Getty R. (ed): Sisson and Grossman's the Anatomy of the Domestic Animals. 5th ed., 528, WB Saunders Company, Philadelphia.

Konig HE, Liebich HG. 2007. Veterinary Anatomy of Domestic Mammals. Third Edition. Stuttgart: Schattauer, pp.:391-405.

Kurtul I, Dursun N, Ozcan S. 2002. Relation of arterial vascularation of the kidney and the adrenal gland of the German shepherd dogs. Istanbul Univ. Vet. Fak. Derg., 28: 65-71.

Loukas M, Aparicio S, Beck A. 2005. Rare case of right accessory renal artery originating as a common trunk with the inferior mesenteric artery: a case report. Clin. Anat., 18: 530-535.

Marques-Sampaio BP, Pereira-Sampaio MA, Henry RW, Favorito LA. 2007. Dog kidney: anatomical relationships between intrarenal arteries and kidney collecting system. Anat. Rec., 290: 1017-1022.

Mazensky D, Flesarova S. 2017. Arrangement of Renal Arteries in Guinea Pig. Anat. Rec., 300: 556-559.

Mazensky D, Purzyc H, Danko J. 2012. Variation in the vascular anatomy of the rabbit kidney and its experimental significance. Acta Sci. Pol. Med. Vet., 11: 25-34.

Mohamed RAA. 2014. Double renal artery in Baladi rabbit. Inter. J. Vet. Sci., 33: 105-108.

Nerantsiz C, Antonakis E, Avgaustakis D. 1978. A new corrosion casting technique. Anatomical Record, 191: 321-325.

Nickel R, Scummer A, Seiferle E. 1979. The viscera of domestic animals. Ed New York: Springer, pp.: 294.

Nickel R, Schummer A, Seiferle E. 1981. The Anatomy of the Domestic Animals. Vol.3. Verlag Paul Parey, Berlin and Hamburg.

Nowicki W, Brudnicki M, Iwanczyk R, Skoczylas B. 2010. Branches of the abdominal aorta in European rabbit. EJPAU, 13:10. 
Nur IH, Yoldas, A. 2011. The branches variation of the renal artery in a Wistar rat. Journal Faculty of Veterinary Medicine, Erciyes University, 8: 211-216.

Ozudogru Z, Ozdemir D. 2005. Intrarenal arterial patterns in the wolf. Vet. Med., 50: 411-414.

Ozudogru Z, Ozdemir D, Can M, Aksoy G. 2018. Anadoludaki kız1 tilkinin (Vulpes vulpes leinnoleus 1758) arteria renalis'inin intrarenal segmentasyonu ve biometrik ölçümleri. Harran Vet. Bil. Derg., 7: 173-178.

Ozdemir D, Ozudogru Z, Malkoc I. 2009. Intrarenal segmentation of the renal arteries in the Kangal dog. Kafkas Univ. Vet. Fak. Derg., 15: 41-44.

Pereira-Sampaio MA, Marques-Sampaio BPS, Henry RW, Favorito LA, Sampao FJB. 2009. The dog kidney as experimental model in endourology: Anatomic contribution. J. Endourol., 23: 989-993.
Paryani MR. 2012. Intrarenal patterns of the vascular supply in one humped camel (Camelus dromedarius). Ann. Biol. Res., 3: 4947-4950.

Shively MJ. 1978. Origin and branching of renal arteries in the dog. Journal of American Veterinary Medicine Associated, 173: 986-989.

Tompset DH. 1970. Anatomical Techniques. 2 nd ed. E. and S. Livingstone, Edinburg and London.

Tufan M, Akmaz, A. 2001. Güney Karaman (Karakoyun), Kangal-Akkaraman ve Akkaraman Kuzularının farklı kesim ve karkas ağırlıklarında kesim ve karkas özellikleri. Turkish J. Vet. and Anim. Sci., 25: 495-504.

Wiland C, Indykiewicz P. 1999. Multiple renal arteries (Aa. renales) in mink and dog. Electronic Journal of Polish Agricultural Universities, 2: 14.

Yoldas A, Aydin A, Ilgun R. 2014. Macroscopic distribution of the renal artery and intrarenal arteries in mole rats (Spalax leucodon). Vet. Med., 59: 382-387. 